\title{
Adipose-Derived Stromal Cells from Lipomas: Isolation, Characterisation and Review of the Literature
}

\author{
Mathias Tremp ${ }^{a}$ Nadia Menzi $^{a}$ Laurent Tchang $^{a}$ Pietro G. di Summa \\ Dirk J. Schaefer ${ }^{\mathrm{a}}$ Daniel F. Kalbermatten ${ }^{\mathrm{a}}$ \\ ${ }^{a}$ Department of Plastic, Reconstructive, Aesthetic and Hand Surgery, University Hospital Basel, Basel, and ${ }^{b}$ Division of \\ Plastic, Reconstructive and Aesthetic and Hand Surgery, CHUV, University Hospital of Lausanne, Lausanne, Switzerland
}

\section{Key Words}

Adipocytes · Lipomatosis · Proliferation · Stem cells .

Tissue engineering

\begin{abstract}
Objective: The aim of this study was to characterize adiposederived stromal cells (ADSCs) from patients diagnosed with multiple symmetric lipomatosis (MSL) in order to obtain potentially new insights into the pathophysiology, pathogenesis and treatment of this disease. Methods: Cells from the stromal vascular fraction were analysed by the colony-forming efficiency assay and flow cytometry using standard markers. Moreover, the power of adipogenic plasticity was evaluated. Finally, a literature review was performed from 1982 to 2015 using the US National Institutes of Health's PubMed database. Results: Three European-descent patients diagnosed with either MSL type I or II could be identified for analysis. The resulting mean colony-forming efficiency assay was $14.3 \pm 5 \%$. Flow-cytometric analysis of the ADSCs revealed high levels of CD34 (70 $\pm 9 \%), C D 45(37 \pm 13 \%)$ and CD73 (55.8 $\pm 14 \%)$, whereas low levels of CD31 (16.8 $\pm 14 \%)$ and CD105 (5.8 $\pm 0.7 \%)$ were detected. Furthermore, ADSCs showed a strong adipogenic potential, which is in line with the literature review. The stem cell pool in lipoma shows several alterations in biological activities, such as proliferation,
\end{abstract}

apoptosis and stemness. Conclusions: ADSCs from lipoma may be interesting in the application of regenerative medicine. We discuss possible molecular treatment options to regulate their activities at the source of the MSL.

(c) 2016 S. Karger AG, Basel

\section{Introduction}

Lipoma is one of the most common soft-tissue mesenchymal neoplasms in adults and can be located in any part of the body [1]. Multiple symmetric lipomatosis (MSL) is a rare disorder and largely more prevalent in males of Mediterranean descent [2]. The disease can be defined as type I MSL if the fatty tumours maintain the aspect of distinct, well-circumscribed, grossly round masses protruding from the body surface [3]. Type II disease is characterized by extensive, diffuse involvement of lipomatous tissue in the subcutaneous fat layer, giving the patients the appearance of simple obesity [3].

Details of the cellular and molecular phenomena underlying the pathogenesis of this disease remain unclear, although there are reports of proliferative activity and chromosomal aberrations of lipoma adipocytes from the brown adipose tissue $[4,5]$. Furthermore, an association between metabolic disorders and alcoholism has been

\section{KARGER}

E-Mail karger@karger.com

www.karger.com/pat
(C) 2016 S. Karger AG, Basel

$1015-2008 / 16 / 0835-0258 \$ 39.50 / 0$
Prof. Dr. Dr. Daniel F. Kalbermatten, MD, PhD

Plastic, Reconstructive, Aesthetic and Hand Surgery

University Basel, Spitalstrasse 21

$\mathrm{CH}-4031$ Basel (Switzerland)

E-Mail Daniel.Kalbermatten@usb.ch 
postulated [6-8]. Interestingly, it has been reported that chemotherapy and/or blood stem cell transplantation may be plausible causes of de novo multiple lipomatosis, possibly by stem cell mobilization following transplantation or chemotherapy [9]. Lastly, there is an association between the myoclonus epilepsy and ragged-red fibre syndrome and axial multiple lipomas [10].

In the literature, involvement of adipose-derived stromal cells (ADSCs) in the development of lipomas has been proposed [11-14]. However, the involvement of ADSCs in the impaired adipose tissue expandability is only beginning to be explored. Dysregulation of ADSC adipogenesis can lead to ectopic adipose tissue formation, as in the case of lipoma [15]. The presence of ADSCs in lipomas with a differentiation potential similar to that of regular ADSCs has been shown in previous studies [11, $12,16,17]$. Potentially, ADSCs from useless tissue may be an attractive cell source for the application of regenerative medicine [18]. The cells residing in fat stroma revealed a wide range of functional properties in vivo as well as differentiation potential in vitro. One of the significant practical factors supporting the therapeutic use is the potential to readily obtain an autologous preparation of these cells for injection within the time frame of 1-2 $\mathrm{h}$ [19]. Furthermore, it has been supported by many studies that paracrine effects play dominant roles in the therapeutic function of ADSCs. Interestingly, ADSCs can be reprogrammed to induce pluripotent stem cells more efficiently than other cell types. They are immunoprivileged cells and secrete immunomodulatory, angiogenic, anti-apoptotic and haematopoietic factors that facilitate tissue repair [15].

Thus, stem cell-based therapy hold promise for treating acquired and genetic diseases and has been utilized in animal models and human clinical trials, such as wound healing, tissue repair, cardiovascular disorders [19], congenital muscular dystrophy [18] or lower genito-urinary dysfunction [20].

Thus, the aim of this study was twofold: (1) to isolate and characterise ADSCs from patients diagnosed with MSL type I or II and (2) to review the literature and to evaluate the approaches that can explain the disorder at the level of ADSCs.

\section{Patients and Methods}

Patients diagnosed with either MSL type I or II and whole-body involvement were included. Informed written consent for molecular analysis was obtained from all patients, and the Institutional Review Board approved the study [EKBB (Ethics Committee from
Basel) reference No. 78/07]. All human experiments were conducted in accordance with the Declaration of Helsinki (1964). The surgical procedure was performed as described previously [21]. Briefly, preoperative markings were performed with the patient in the standing position. Then, $2-3$ access incisions of $<1 \mathrm{~cm}$ were made at the periphery of the lesions. Infiltration of tumescent solution consisting of Ringer's lactate supplemented with adrenaline $(1: 1,000,000)$ and lidocaine $(0.075 \%)$ was performed. For liposuction, the $\mathrm{PAL}^{\circledR}$ LipoSculptor ${ }^{\mathrm{TM}}$ (MicroAire) was used. An electric speed motor generates a reciprocating motion at 4,000 cycles/min (forward and backward) in the cannula and produces a 2-mm excursion at the tip [21].

\section{Isolation of ADSCS}

Samples of fresh lipo-aspirates were enzymatically digested in $0.075 \%$ collagenase type II ( $355 \mathrm{U} / \mathrm{mg}$; Worthington, Lakewood, N.J., USA) for $60-90 \mathrm{~min}$ at $37^{\circ} \mathrm{C}$ on an orbital shaker. After centrifugation at $300 \mathrm{~g}$ for $10 \mathrm{~min}$, the lipid-rich layer was discarded and the resulting pellet washed with complete medium (CM), consisting of $\alpha$-MEM supplemented with $10 \%$ fetal bovine serum (FBS), $1 \%$ HEPES, $1 \%$ sodium pyruvate and $1 \%$ penicillin-streptomycin-glutamine $(\times 100)$ solution (all from Gibco, www.invitrogen.com) and filtered with a $100-\mu \mathrm{m}$ strainer (BD Falcon; BD Biosciences, San Diego, Calif., USA, http://www.bdbiosciences. com). Lysis of remaining erythrocytes was achieved by incubation for $10 \mathrm{~min}$ at $4^{\circ} \mathrm{C}$ in ammonium chloride solution (Stemcell Technologies, Grenoble, France). Finally, the solution was filtered with a $70-\mu \mathrm{m}$ strainer and the cells resuspended in CM. Total cell numbers were assessed by staining with crystal violet (Sigma) and counting of the nucleated cells in a Neubauer chamber.

\section{Cell Characterisation}

Freshly isolated ADSCs were characterised by fluorescenceactivated cell-sorting (FACS) analysis. The cells were incubated for $30 \mathrm{~min}$ at $4^{\circ} \mathrm{C}$ with fluorochrome-conjugated antibodies against the indicated antibodies or an isotype control. Antibodies used were: CD31-fluorescein isothiocyanate (FITC) and CD34APC (endothelial markers), CD45-PE (panhaematopoietic marker), CD73-APC (all from BD Biosciences) and CD105-FITC (AbD Serotec, Oxford, UK; mesenchymal markers). Cells were washed and resuspended in FACS buffer (PBS, $0.5 \%$ human serum albumin, 0.5 mM EDTA) and analysed with a FACSCalibur flow cytometer (BD Biosciences USA). The data were analysed using FlowJo software v. 10.0.6 (Tree Star Inc., Ashland, Oreg., USA) and expressed as the percentage of positive cells determined by flow cytometry.

\section{Colony-Forming Efficiency Assay}

The number of clonogenic cells was evaluated by the colonyforming efficiency assay as described previously [22]. Briefly, cells were plated at clonal density $\left(9 \mathrm{cells} / \mathrm{cm}^{2}\right)$ and cultured in $\alpha$-MEM (Gibco) with $10 \% \mathrm{FBS}$ and $5 \mathrm{ng} / \mathrm{ml}$ fibroblast growth factor (FGF)2. After 2 weeks, cells were washed with PBS, fixed with 3.7\% formaldehyde in PBS, stained with crystal violet (Sigma) for $10 \mathrm{~min}$ and washed with tap water, and then colonies were counted. In order to exclude possible sporadic macrophage aggregates, only colonies that were macroscopically visible and composed of fibroblastic cells were considered. All determinations were performed in triplicate [22]. 

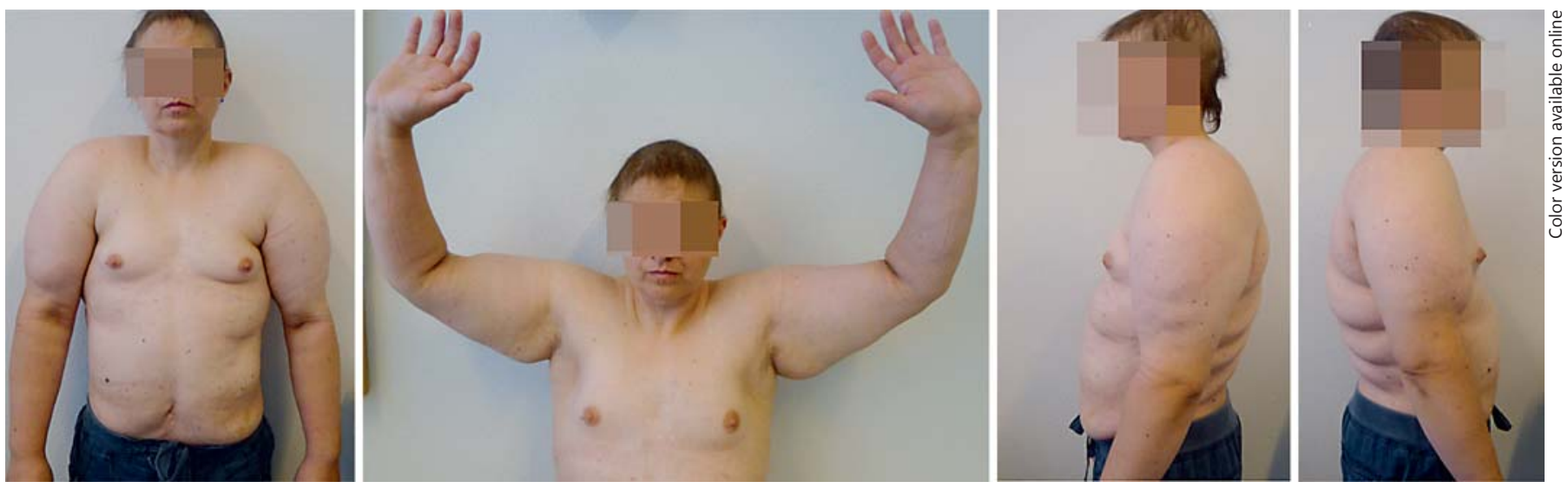

Fig. 1. Representative figure of a 37-year-old female patient with MSL type II before lipoplasty of the upper arms.

\section{Adipogenic Differentiation}

To further demonstrate the power of adipogenic plasticity of ADSCs, cells were differentiated toward the adipocyte lineage, as previously reported $[23,24]$. Briefly, stromal cells were isolated using $0.15 \%$ collagenase digestion as well as washing and centrifugation cycles. Then, adipocyte differentiation was induced after seeding $2 \times 10^{4}$ cells/well on 6 -well tissue culture plastic dishes and growing them with Dulbecco's modified Eagle's medium [DMEM $(\times 1)$ ] supplemented with $10 \%$ FBS, $1 \%$ HEPES, $1 \%$ sodium pyruvate and $1 \%$ penicillin-streptomycin-glutamine $(\times 100$; all from Gibco) until 95\% confluence. To induce adipogenic differentiation, the $10 \%$ DMEM solution was supplemented with $10 \mu \mathrm{g} / \mathrm{ml}$ insulin, $1 \mu \mathrm{M}$ dexamethasone, $100 \mu \mathrm{M}$ indomethacin and $0.5 \mathrm{mM}$ 3 -isobutyl-1-methylxanthine for the first $72 \mathrm{~h}$ and then with $10 \mu \mathrm{g} /$ $\mathrm{ml}$ insulin for the next $24 \mathrm{~h}$ [25]. Three differentiation cycles of $96 \mathrm{~h}$ were performed as previously described. The cells were washed once with PBS, fixed with $4 \%$ formaldehyde, stained with oil red O 0.3\% (Sigma) and photographed with an Olympus IX50 microscope (Olympus Corporation, Tokyo, Japan). The staining was solubilized with isopropanol (Emsure; Merck Millipore, Billerica, Mass., USA) and quantified by measuring absorbance at 500 $\mathrm{nm}$ with a Synergy $\mathrm{H} 1$ hybrid multimode spectrofluorometer. The differentiated ADSCs were compared to BLK (= blank, pure isopropanol) and non-differentiated ADSCs, which were cultured in $\mathrm{CM}$ during the same time period.

Data are presented as means \pm SD (GraphPad Prism version 5.00 for Mac OS X; GraphPad Software, San Diego, Calif., USA, www.graphpad.com).

\section{Literature Search Strategy}

A literature review was performed from 1982 to 2015 using the US National Institutes of Health's PubMed database. The reference lists of all selected papers were further reviewed for potentially relevant analysis. Eligible reports were full papers written in English language reporting on the pathophysiology of lipoma and ADSCs.

\section{Article Selection}

Combinations of the following key words were used: 'lipoma' and 'stem cells'. Totally, 36 articles were identified. Of those, 30 were included in the review: there were 12 case reports $[1,9-11$, 26-34], 12 reports on basic science or animal studies [4, 12, 13, $35-44], 2$ case series [14, 45] and 4 systematic reviews [13, 38, 46, 47]. Totally, more than 60 patients were analysed; 25 articles were studied as a full-text version.

\section{Results}

Two male and 1 female, European-descent patients aged between 37 and 55 years (mean $49 \pm 10$ years) were identified and diagnosed with MSL. Two patients were diagnosed with MSL type II (fig. 1), whereas 1 patient was diagnosed with MSL type I.

\section{Characterization of ADSCs and Colony-Forming \\ Efficiency Assay}

Taken all the results pooled together, flow-cytometric analyses of the ADSCs revealed high levels of CD34, CD45 and CD73, but low levels of CD31 and CD105 were detected (fig. 2). The results of the patients'ADSCs compared to regular ADSCs from historical normal patients are shown in table 1 . The resulting mean of the colonyforming efficiency assay, which is an approximation to the frequency of progenitor cells within the adipose tissue in isolated ADSCs, was $14.3 \pm 5 \%$.

\section{Adipogenic Differentiation}

We confirmed adipogenesis 2 weeks after induction by oil red $\mathrm{O}$ staining, showing intracellular lipoid droplets of variable sizes (fig. 3). Semi-quantitative analysis showed a high amount of lipoid droplets in the differentiated ADSCs (10.2 $\pm 0.4 \mathrm{OD})$. 
Fig. 2. Representative flow-cytometric analysis of undifferentiated lipoma-derived multipotent mesenchymal stromal cells derived from an individual donor were stained with monoclonal antibodies directed against either CD34, CD31, CD45, CD73 or CD105 and coupled to FITC. An isotype-matched monoclonal antibody served as a control.
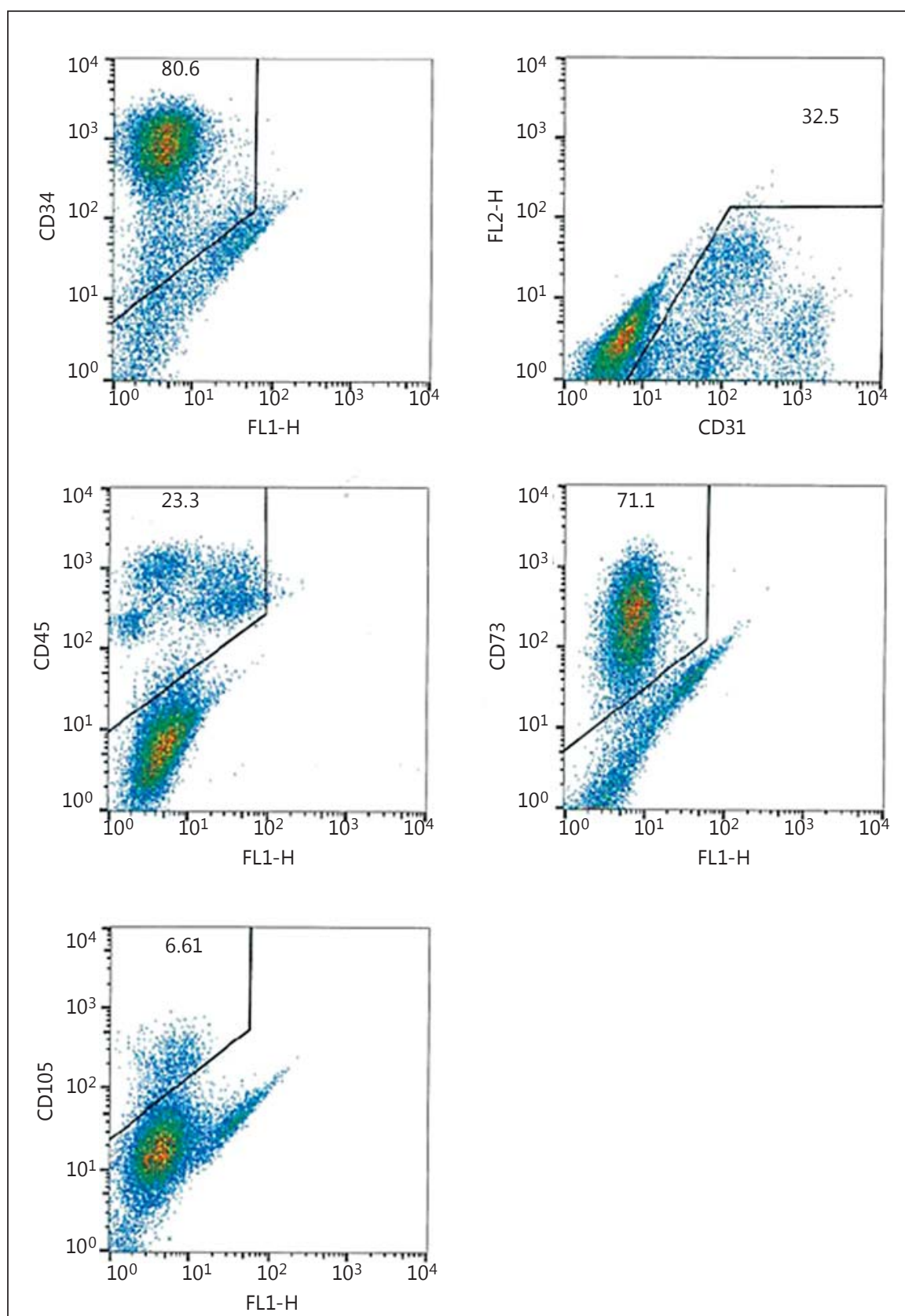

\section{Discussion}

The clinical expression of MSL is sex related: in type I MSL, lipomatous tissue is located around the neck, upper trunk and arms. This type occurs in men; patients are usually underweight and uninvolved subcutaneous tissue is often reduced or even atrophic [48]. Type II MSL affects both men and women and is characterized by adipose tissue accumulation in the upper back, deltoid regions, up- per arms, hips and thigh regions [48]. It is suggested that there is a causal relationship between higher alcohol consumption and MSL expression [48], which we observed in 2 patients from our case series. Furthermore, the accumulation of subcutaneous fat leads to changes in the subcutaneous/visceral fat content ratio, and this may reduce insulin resistance analogous to the action of antidiabetic drugs like peroxisome-proliferator-activated $\gamma$-receptor agonists (thiazolidinediones) [48]. It remains speculative 
Fig. 3. Representative photomicrographs from controls (undifferentiated ADSCs) and ADSCs under adipogenic conditions (a). Adipogenic cultures (undifferentiated ADSCs) (b) were stained with oil red O 14 days after induction (c).

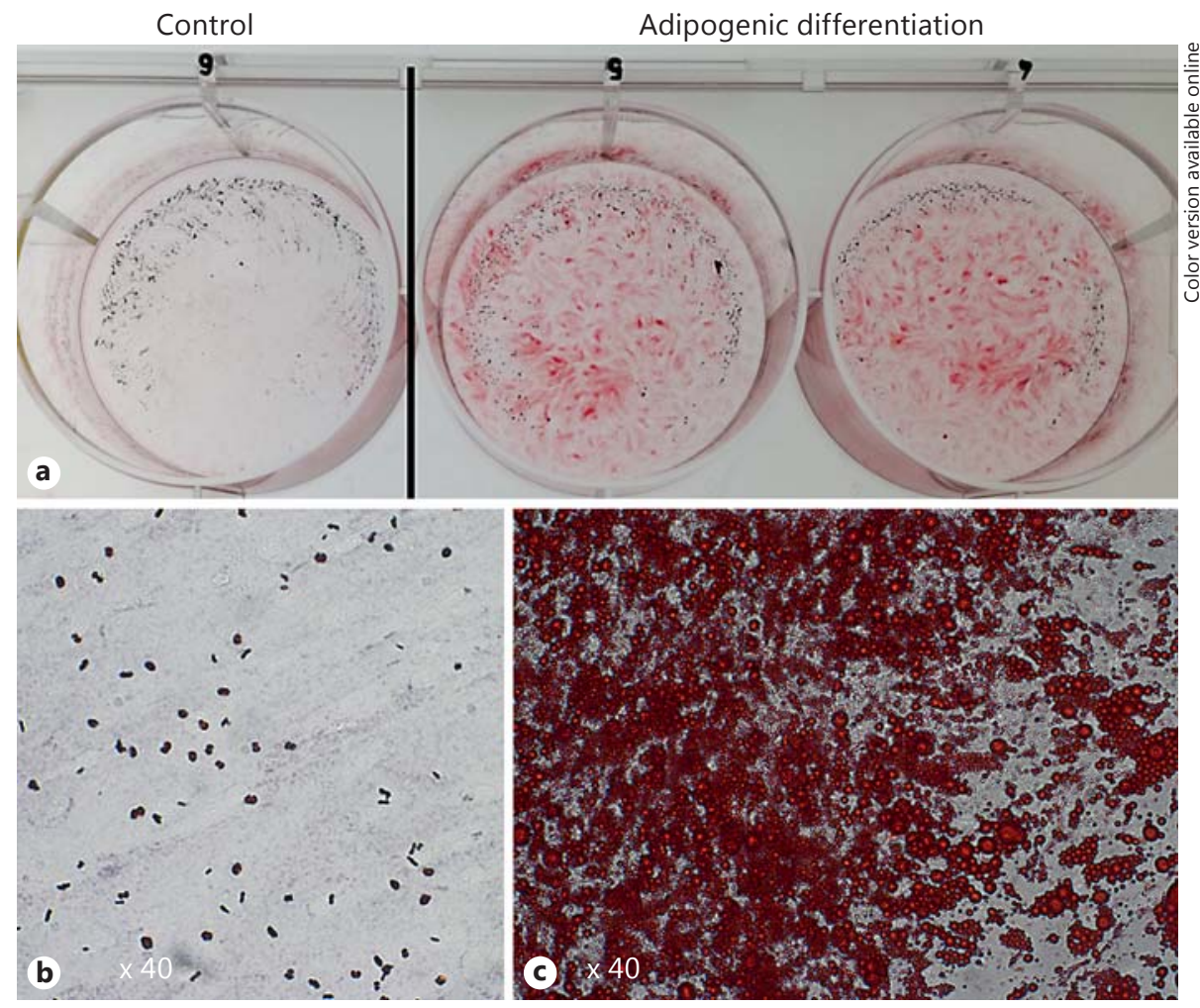

Table 1. Characterisation of ADSCs from patients diagnosed with MSL

\begin{tabular}{|c|c|c|c|c|c|c|c|c|c|}
\hline $\begin{array}{l}\text { Pati- } \\
\text { ent }\end{array}$ & $\begin{array}{l}\text { Sex/age, } \\
\text { years }\end{array}$ & Diagnosis & $\begin{array}{l}\text { Donor } \\
\text { site }\end{array}$ & $\begin{array}{l}\text { CFU-f, } \\
\%\end{array}$ & $\begin{array}{l}\text { CD31, } \\
\%\end{array}$ & $\begin{array}{l}\text { CD34, } \\
\%\end{array}$ & $\begin{array}{l}\text { CD45, } \\
\%\end{array}$ & $\begin{array}{l}\text { CD73, } \\
\%\end{array}$ & $\begin{array}{l}\text { CD105, } \\
\%\end{array}$ \\
\hline 1 & $\mathrm{M} / 55$ & $\begin{array}{l}\text { MSL type I } \\
\text { History of alcohol consumption } \\
\text { Hepatic disease } \\
\text { Hypertriglyceridemia }\end{array}$ & $\begin{array}{l}\text { Lower } \\
\text { back and } \\
\text { neck }\end{array}$ & $11.9 \pm 1.0$ & 10.6 & 66.0 & 39.1 & 53.3 & 5.2 \\
\hline 3 & $\mathrm{~F} / 37$ & $\begin{array}{l}\text { MSL type II } \\
\text { Diabetes mellitus II } \\
\text { Hypertriglyceridemia } \\
\text { Hyperuricemia } \\
\text { Kidney disease }\end{array}$ & $\begin{array}{l}\text { Upper } \\
\text { arms }\end{array}$ & $20.8 \pm 0.3$ & NA & NA & NA & NA & NA \\
\hline
\end{tabular}

References 57, 59, 67-69

$\begin{array}{llllll}3.125 \pm 2.1-13 \pm 5 & 21.8 \pm 10.8 & 60.0 \pm 11.5 & 17.6 \pm 7.7 & 25.0 \pm 6.2 & 4.9 \pm 3.5\end{array}$

Data are presented as means \pm SD. NA $=$ Not available. 
whether hyperinsulinemia and alcohol consumption have a synergistic impact on the extent of the disease. Nevertheless, it is suggested that, in addition to the cessation of alcohol consumption, the reduction in blood glucose and lipid concentrations by medication may also assist in resolving the accumulated fat of type I MSL in patients with non-insulin-dependent diabetes mellitus [49].

MSL, a mitochondrial disorder derived from vestigial brown fat, is characterised by the development of axial lipoma $[10,50]$. Complete removal is almost impossible and recurrences inevitable, among others due to the underlying primary metabolic defect, lack of encapsulation, the large size and anatomic distribution of the lesions [21, 51]. Furthermore, lipoma-derived stem cells have been suggested to play an important role in lipoma recurrence after lipoma liposuction [52].

In our study, molecular analysis of diseased adipose tissue of whole-body-affected patients revealed a high ADSC number in the colony-forming efficiency assay. Furthermore, strong adipogenic plasticity has been observed in vitro. In addition, ADSCs showed a high expression of CD34, CD45 and CD73, and low levels of CD31 and CD105, respectively. Although this cell characterisation is not in line with the minimal set of standard criteria of multipotent mesenchymal stromal cells [53], ADSCs may have a different cell phenotype [15]. Potentially, the positivity of CD34 and CD31 might be characteristic for these cells, given the tumoural feature of ADSCs. This is in line with the recent literature, which suggested that CD34+ lipoma cells showed higher vasculogenic properties and increased resistance in aging [14]. The potential roles of the CD34 family include increasing proliferation (replicative capacity) and blocking differentiation of stem or progenitor cells that therefore maintain their undifferentiated progenitor/stem cell phenotype (immaturity or stemness of the cells) [14]. However, a limitation of our study is the lack of ADSCs obtained from subcutaneous adipose tissue from the same donor to really compare biological characteristics of ADSCs from lipoma.

ADSCs from lipoma tissue have been shown to transform into various histological characteristics and types such as angiolipoma, lipoma, myolipoma, lipomatous neurofibroma, osteolipoma or osteochondrolipoma [1, 11, 29-32]. In 2007, Lin et al. [12] described for the first time putative ADSCs from lipoma tissue with characteristics similar to regular ADSCs but with no evidence of malignant transformation. ADSCs from lipomas showed a significantly higher proliferative capacity than regular ADSCs with increased numbers of Ki67+/CD34+ and the ability to differentiate into fat, bone or cartilage [23]. This 'multipotency' may be derived from different progenitor cell types within the lipoma.

Furthermore, it was observed that CD34+ ADSCs aggregate around small adipocytes in lipoma tissue, also called adipogenic/angiogenic cell cluster, which is suggestive of adipocyte neogenesis [41]. Interestingly, it has also been proposed that brown adipocyte precursors arise in close association with vessel walls [27]. Lastly, it has been suggested that there is a close histogenetic link between lipomatous and angiomyofibromatous processes induced by perivascular stem cells [28, 45].

Our results, which confirm a high turnover of adipocytes, are in line with previous studies $[14,23,54,55]$. The colony-forming unit-fibroblast (CFU-f) assay is a popular method to evaluate stem cell capacity [56]. In general, the frequency of stromal progenitors ranges from 1 to $10 \%$ of the total nucleated cell population. In our study, however, the CFU-f assay showed a higher frequency $(14.3 \pm 5 \%)$ in MSL patients [57]. Importantly, it is known that FGF improves ADSC proliferation [58]. This was confirmed in a recent study [59] where CFU-f was determined by plating stromal vascular fraction cells cultured in CM containing FGF, showing a high proliferation rate (>10\%) [59].

It has been suggested that high mobility group (HMG) proteins act as architectural factors and coordinate cell proliferation and differentiation in adult adipose tissue $[36,37,46]$. Research revealed that the HMGA2 gene is frequently disrupted in human solid tumours of a differentiated mesenchymal origin such as lipoma [46]. Furthermore, it has been postulated that PPAP2B, a member of the lipid phosphate phosphatases family, plays a role in human adipogenesis [36]. Finally, pRB, a product of the human RB-1 gene, might play a key role in adipogenesis [39].

The cumulative population-doubling level of lipoma ADSCs is significantly higher than that of regular ADSCs [23]. Thus, they possess a potent proliferation potential in less time than regular ADSCs [23]. In a study by Qian et al. [55], there were significant differences between regular ADSCs and lipoma ADSCs in the biological characteristics in vitro in terms of in vitro biological features. In this study, regular ADSCs showed a significantly lower proliferation capacity than ADSCs from lipoma, as evidenced by MTS chromatometry (= assay for assessing cell metabolic activity).

Apoptosis represents a process of programmed cell death [60]. It has been proposed that cellular apoptosis is not enhanced in lipoma, suggesting that the enlargement of lipoma tissue may be due to a positive balance of adipocyte turnover (accelerated adipogenesis combined with non-enhanced apoptosis) [41]. In a recent study by 
Zavan et al. [14], increased expression of genes associated with the increased negative regulation of the apoptotic event and down-regulation of apoptotic markers have been found in lipoma tissue. Although adipogenesis is accelerated in lipoma, lipoma tissue escapes from hypoxia and does not show macrophage infiltration, subsequent inflammatory changes or enhanced apoptosis [41]. It has been postulated that angiogenesis may be successfully increasing alongside adipogenesis, explaining the reason for the maintenance of oxygen pressure in lipoma [41]. Indeed, our results suggest increased adipogenesis and neoangiogenesis, confirmed by a high expression of CD34+ in our cell population. CD34 has been suggested to be an excellent marker of neoangiogenesis; it has been used to highlight the microvasculature vessel density as a direct marker of the degree of neoangiogenesis [61]. It is a highly glycosylated transmembrane cell surface glycoprotein expressed by haematopoietic stem and progenitor cells and presents on the luminal cell membrane of quiescent endothelial cells of small blood vessel and lymphatics [62]. In lipoma tissue, the persistence of CD34 positivity is associated with increased replicative capacity and maintenance of cell immaturity [14]. Importantly, CD34+ cells regulate stromal collagen content and help to activate local fibroblasts through increased proliferative capacity, stimulation of growth factors and extracellular matrix protein [14].

It has been shown that passaged human ADSCs reduce their expression of surface histocompatibility antigens and no longer stimulate a mixed lymphocyte reaction when co-cultured with allogeneic peripheral blood monocytes [13]. Potentially, transplanted allogeneic ADSCs will not elicit a robust immune response and subsequent rejection [13]. Thus, they may have potential therapeutic use as allogeneic products for tissue engineering and for gene therapy upon genetic modification as well [40]. That being said, genetic stability of these cells is of paramount importance [40]. Interestingly, it has also been shown that ADSCs are deficient in gap-junctional intercellular communication [23]. Moreover, it has been suggested that the $\beta_{3}$-adrenergic receptor is the functionally relevant adrenergic receptor subtype in brown adipocytes and that its stimulation by noradrenaline modulates the expression of genes, such as uncoupling protein-1 and inducible nitric oxide synthase, involved in fat cell proliferation and differentiation [63]. The failure of noradrenaline to induce nitric oxide synthase production seems to be involved in the dysregulated proliferation and differentiation (i.e. mitochondrial biogenesis) of ADSCs [63].
Thus, undifferentiated ADSCs might be potential major modulators of MSL. Next to the obvious application of ADSCs as precursors of differentiated cells for cell replacement, the unique immune biology and secretome of ADSCs are increasingly appreciated for their therapeutic potential [15]. As ADSCs are immunoprivileged due to the lack of expression of class II major histocompatibility complex and co-stimulatory molecules on the cell surface, this potentially allows allogeneic transplantation of ADSCs into immunocompetent recipients with minimal immune reaction in the host [64]. Furthermore, ADSCs also secrete an array of soluble factors that promote tissue regeneration at the injury site via a paracrine mechanism. The secretome includes angiogenic factors, anti-apoptotic factors, haematopoietic factors and hepatocyte growth factor. It is now suggested that the effects of ADSC therapy in vivo are largely attributable to the paracrine and immunomodulatory effects of ADSCs rather than the cell replacement per se [65]. Interestingly, ADSCs are also ideal for reprogramming into induced pluripotent stem cells [15]. It has been shown that reprogramming somatic cells from patients with mitochondrial DNA disorders can yield pluripotent stem cells with varying burdens of heteroplasmy, which might be useful in the study and treatment of mitochondrial diseases such as MSL [66].

\section{Conclusions}

The properties and knowledge of ADSCs from lipoma bear the hope of making useless tissue useful in the application of tissue engineering and regenerative medicine. Eventually, a better understanding of ADSC features from lipoma (multipotency of clonal cells, serial transplantation assays, in vivo studies, migration, cytokine profiles, proliferation ability, dual labelling and complete FACS analysis) together with the determination of coexpression markers on the same cell by immunohistochemistry of the lipoma tissue compared to a formal control group may be useful to regulate their activities and to slow their metabolism at the source of the MSL.

\section{Acknowledgements}

We thank Charles Rudin for his contributions in the preparation of the figures.

\section{Disclosure Statement}

The authors have no conflict of interest.
Tremp/Menzi/Tchang/di Summa/ Schaefer/Kalbermatten 


\section{References}

1 Gultekin SE, Kahraman S, Karadayi K: Parosteal osteochondrolipoma of the mandible. J Oral Maxillofac Pathol 2012;16:280-282.

2 Guilemany JM, Romero E, Blanch JL: An aesthetic deformity: Madelung's disease. Acta Otolaryngol 2005; 125:328-330.

3 Enzi G, Busetto L, Ceschin E, Coin A, Digito M, Pigozzo S: Multiple symmetric lipomatosis: clinical aspects and outcome in a longterm longitudinal study. Int J Obes Relat Metab Disord 2002;26:253-261.

4 Kolokol'chikova EG, Pal'tsyn AA, Shchegolev AI, Adamyan AA, Chervonskaya NV: Proliferative activity of adipocytes in adipose tissue tumors. Bull Exp Biol Med 2005;140:122-126.

5 Willen H, Akerman M, Dal Cin P, De Wever I, Fletcher CD, Mandahl N, Mertens F, Mitelman F, Rosai J, Rydholm A, Sciot R, Tallini G, Van den Berghe H, Vanni R: Comparison of chromosomal patterns with clinical features in 165 lipomas: a report of the CHAMP study group. Cancer Genet Cytogenet 1998;102:4649.

6 Banerjee SP, Sharma VK, Khanna JM: Alterations in beta-adrenergic receptor binding during ethanol withdrawal. Nature 1978;276: 407-409.

7 Mevio E, Sbrocca M, Mullace M, Viglione S, Mevio N: Multiple symmetric lipomatosis: a review of 3 cases. Case Rep Otolaryngol 2012; 2012:910526

8 Rosato L, Lazzeri D, Campana M, Vaccaro M, Campa A, Ciappi S, Nisi G, Brandi C, Grimaldi L, D’Aniello C: Mesotherapy should not replace the surgical approach in the treatment of benign symmetric lipomatosis. Aesthetic Plast Surg 2011;35:278-280.

9 Bracaglia R, D’Ettorre M, Gentileschi S, Mingrone G, Tambasco D: Multiple lipomatosis after stem cell transplant and chemotherapy: a case report. Eur Rev Med Pharmacol Sci 2014;18:413-415.

10 Holme E, Larsson NG, Oldfors A, Tulinius M, Sahlin P, Stenman G: Multiple symmetric lipomas with high levels of mtDNA with the tRNA(Lys) A-> G(8344) mutation as the only manifestation of disease in a carrier of myoclonus epilepsy and ragged-red fibers (MERRF) syndrome. Am J Hum Genet 1993;52:551556.

11 Makiguchi T, Terashi H, Hashikawa K, Yokoo S, Kusaka J: Osteolipoma in the glabella: pathogenesis associated with mesenchymal lipoma-derived stem cells. J Craniofac Surg 2013;24:1310-1313.

12 Lin TM, Chang HW, Wang KH, Kao AP, Chang CC, Wen CH, Lai CS, Lin SD: Isolation and identification of mesenchymal stem cells from human lipoma tissue. Biochem Biophys Res Commun 2007;361:883-889.

13 Gimble JM, Katz AJ, Bunnell BA: Adiposederived stem cells for regenerative medicine. Circ Res 2007;100:1249-1260.
14 Zavan B, De Francesco F, D’Andrea F, Ferroni L, Gardin C, Salzillo R, Nicoletti G, Ferraro GA: Persistence of CD34 stem marker in human lipoma: searching for cancer stem cells. Int J Biol Sci 2015;11:1127-1139.

15 Ong WK, Sugii S: Adipose-derived stem cells: fatty potentials for therapy. Int J Biochem Cell Biol 2013;45:1083-1086.

16 Virtanen KA, Lidell ME, Orava J, Heglind M, Westergren R, Niemi T, Taittonen M, Laine J, Savisto NJ, Enerback S, Nuutila P: Functional brown adipose tissue in healthy adults. $\mathrm{N}$ Engl J Med 2009;360:1518-1525.

17 Cypess AM, Lehman S, Williams G, Tal I, Rodman D, Goldfine AB, Kuo FC, Palmer EL, Tseng YH, Doria A, Kolodny GM, Kahn CR: Identification and importance of brown adipose tissue in adult humans. N Engl J Med 2009;360:1509-1517.

18 Alexeev V, Arita M, Donahue A, Bonaldo P, Chu ML, Igoucheva O: Human adipose-derived stem cell transplantation as a potential therapy for collagen VI-related congenital muscular dystrophy. Stem Cell Res Ther 2014; $5: 21$.

19 Hong SJ, Traktuev DO, March KL: Therapeutic potential of adipose-derived stem cells in vascular growth and tissue repair. Curr Opin Organ Transplant 2010;15:86-91.

20 Tremp M, Salemi S, Largo R, Andersson KE, Plock JA, Aboushwareb T, Sulser T, Eberli D: Adipose-derived stem cells (ADSCs) and muscle precursor cells (MPCs) for the treatment of bladder voiding dysfunction. World J Urol 2014;32:1241-1248.

21 Tremp M, Wettstein R, Tchang LA, Schaefer DJ, Rieger UM, Kalbermatten DF: Power-assisted liposuction (PAL) of multiple symmetric lipomatosis (MSL) - a longitudinal study. Surg Obes Relat Dis 2015;11:155-160.

22 Mehrkens A, Di Maggio N, Gueven S, Schaefer D, Scherberich A, Banfi A, Martin I: Nonadherent mesenchymal progenitors from adipose tissue stromal vascular fraction. Tissue Eng Part A 2014;20:1081-1088.

23 Meyerrose TE, De Ugarte DA, Hofling AA, Herrbrich PE, Cordonnier TD, Shultz LD, Eagon JC, Wirthlin L, Sands MS, Hedrick MA, Nolta JA: In vivo distribution of human adipose-derived mesenchymal stem cells in novel xenotransplantation models. Stem Cells 2007;25:220-227.

24 Gronthos S, Franklin DM, Leddy HA, Robey PG, Storms RW, Gimble JM: Surface protein characterization of human adipose tissue-derived stromal cells. J Cell Physiol 2001;189: 54-63.

25 Barbero A, Ploegert S, Heberer M, Martin I: Plasticity of clonal populations of dedifferentiated adult human articular chondrocytes. Arthritis Rheum 2003;48:1315-1325.

26 Asher V, van Schalkwyk G, Bali A: Synovial sarcoma of the vulva: a case report. J Med Case Rep 2011;5:95.
27 Manieri M, Murano I, Fianchini A, Brunelli A, Cinti S: Morphological and immunohistochemical features of brown adipocytes and preadipocytes in a case of human hibernoma. Nutr Metab Cardiovasc Dis 2010;20:567-574.

28 Hameed M, Clarke K, Amer HZ, Mahmet K, Aisner S: Cellular angiofibroma is genetically similar to spindle cell lipoma: a case report. Cancer Genet Cytogenet 2007;177:131-134.

29 Rau T, Soeder S, Olk A, Aigner T: Parosteal lipoma of the thigh with cartilaginous and osseous differentiation: an osteochondrolipoma. Ann Diagn Pathol 2006;10:279-282.

30 Alrawi SJ, Deeb G, Cheney R, Wallace P, Loree T, Rigual N, Hicks W, Tan D: Lipomatous hemangiopericytoma of the head and neck: immunohistochemical and DNA ploidy analyses. Head Neck 2004;26:544-549.

31 Horiguchi H, Matsui-Horiguchi M, Fujiwara M, Kaketa M, Kawano M, Ohtsubo-Shimoyamada R, Ohse H: Angiomyofibroblastoma of the vulva: report of a case with immunohistochemical and molecular analysis. Int J Gynecol Pathol 2003;22:277-284.

32 Val-Bernal JF, de sa Dehesa J, Garijo MF, Val D: Cutaneous lipomatous neurofibroma. Am J Dermatopathol 2002;24:246-250.

33 Ishizawa K, Kan-nuki S, Kumagai H, Komori T, Hirose T: Lipomatous primitive neuroectodermal tumor with a glioblastoma component: a case report. Acta Neuropathol 2002; 103:193-198.

34 Nalesnik MA, Martinez AJ, Heros RC: Intracranial lipoma with hematopoietic elements (myelolipoma): report of a case with successful surgical resection. Cancer 1982;50:295299

35 Qu Z, Yu J, Ruan Q: TGF- $\beta 1$-induced LPP expression dependant on Rho kinase during differentiation and migration of bone marrowderived smooth muscle progenitor cells. J Huazhong Univ Sci Technolog Med Sci 2012; 32:459-465.

36 Bianchini L, Birtwisle L, Saada E, Bazin A, Long E, Roussel JF, Michiels JF, Forest F, Dani C, Myklebost O, Birtwisle-Peyrottes I, Pedeutour F: Identification of PPAP2B as a novel recurrent translocation partner gene of HMGA2 in lipomas. Genes Chromosomes Cancer 2013;52:580-590.

37 Thies HW, Nolte I, Wenk H, Mertens F, Bullerdiek J, Markowski DN: Permanent activation of HMGA2 in lipomas mimics its temporal physiological activation linked to the gain of adipose tissue. Obesity (Silver Spring) 2014;22:141-150.

38 Diaz-Flores L, Gutierrez R, Garcia MP, Saez FJ, Diaz-Flores L Jr, Valladares F, Madrid JF: CD34+ stromal cells/fibroblasts/fibrocytes/ telocytes as a tissue reserve and a principal source of mesenchymal cells. Location, morphology, function and role in pathology. Histol Histopathol 2014;29:831-870. 
39 Calo E, Quintero-Estades JA, Danielian PS, Nedelcu S, Berman SD, Lees JA: Rb regulates fate choice and lineage commitment in vivo. Nature 2010;466:1110-1114.

40 Altanerova V, Horvathova E, Matuskova M, Kucerova L, Altaner C: Genotoxic damage of human adipose-tissue derived mesenchymal stem cells triggers their terminal differentiation. Neoplasma 2009;56:542-547.

41 Suga H, Eto H, Inoue K, Aoi N, Kato H, Araki J, Higashino T, Yoshimura K: Cellular and molecular features of lipoma tissue: comparison with normal adipose tissue. $\mathrm{Br} J$ Dermatol 2009;161:819-825.

42 Herrera-Herrera ML, Zapata-Bustos R, Salazar-Olivo LA: Simplified culture techniques for growth and differentiation of murine and human pre-adipocytes for translational applications. Cytotherapy 2009;11:52-60.

43 Petit MM, Lindskog H, Larsson E, Wasteson P, Athley E, Breuer S, Angstenberger M, Hertfelder D, Mattsson E, Nordheim A, Nelander S, Lindahl P: Smooth muscle expression of lipoma preferred partner is mediated by an alternative intronic promoter that is regulated by serum response factor/myocardin. Circ Res 2008;103:61-69.

44 Rehm S, Palmer AE, Harbaugh SW, Rice JM: Infiltrating angiolipoma of skeletal muscle. Transplacental induction in nonhuman primates by N-nitrosoethylurea. Lab Invest 1993;69:111-120.

45 Laskin WB, Fetsch JF, Mostofi FK: Angiomyofibroblastomalike tumor of the male genital tract: analysis of 11 cases with comparison to female angiomyofibroblastoma and spindle cell lipoma. Am J Surg Pathol 1998;22:616.

46 Ashar HR, Chouinard RA Jr, Dokur M, Chada K: In vivo modulation of HMGA2 expression. Biochim Biophys Acta 2010;1799:55-61.

47 Fowler MR, Williams RB, Alba JM, Byrd CR Extra-adrenal myelolipomas compared with extramedullary hematopoietic tumors: a case of presacral myelolipoma. Am J Surg Pathol 1982;6:363-374.

48 Pandzic Jaksic V, Stoos Veic T: Multiple symmetric lipomatosis type 2 in females - report of two cases. Acta Dermatovenerol Croat 2008; 16:31-34

49 Plummer C, Spring PJ, Marotta R, Chin J, Taylor G, Sharpe D, Athanasou NA, Thyagarajan D, Berkovic SF: Multiple symmetrical lipomatosis - a mitochondrial disorder of brown fat. Mitochondrion 2013;13:269-276.

50 Yang CY, Chou CW, Lin MB: Non-insulindependent diabetes mellitus with type I multiple symmetrical lipomatosis: a case report. Zhonghua Yi Xue Za Zhi (Taipei) 1999;62: 167-174.
51 Martinez-Escribano JA, Gonzalez R, Quecedo E, Febrer I: Efficacy of lipectomy and liposuction in the treatment of multiple symmetric lipomatosis. Int J Dermatol 1999;38:551-554.

52 Xu CJ, Cao M, Liu L, Guo LY, Li SL, Liu YH, Yu Y: Nature of the residue hard tissue after liposuction in lipoma and its role in lipoma recurrence (in Chinese). Zhonghua Zheng Xing Wai Ke Za Zhi 2013;29:109-112.

53 Dominici M, Le Blanc K, Mueller I, SlaperCortenbach I, Marini F, Krause D, Deans R, Keating A, Prockop D, Horwitz E: Minimal criteria for defining multipotent mesenchymal stromal cells. The International Society for Cellular Therapy position statement. Cytotherapy 2006;8:315-317.

54 Spalding KL, Arner E, Westermark PO, Bernard S, Buchholz BA, Bergmann O, Blomqvist L, Hoffstedt J, Naslund E, Britton T, Concha H, Hassan M, Ryden M, Frisen J, Arner P: Dynamics of fat cell turnover in humans. Nature 2008;453:783-787.

55 Qian YW, Gao JH, Lu F, Zheng XD: The differences between adipose tissue derived stem cells and lipoma mesenchymal stem cells in characteristics (in Chinese). Zhonghua Zheng Xing Wai Ke Za Zhi 2010;26:125-132.

56 Yang HJ, Kim KJ, Kim MK, Lee SJ, Ryu YH, Seo BF, Oh DY, Ahn ST, Lee HY, Rhie JW: The stem cell potential and multipotency of human adipose tissue-derived stem cells vary by cell donor and are different from those of other types of stem cells. Cells Tissues Organs 2014;199:373-383.

57 Bourin P, Bunnell BA, Casteilla L, Dominici M, Katz AJ, March KL, Redl H, Rubin JP, Yoshimura K, Gimble JM: Stromal cells from the adipose tissue-derived stromal vascular fraction and culture expanded adipose tissue-derived stromal/stem cells: a joint statement of the International Federation for Adipose Therapeutics and Science (IFATS) and the International Society for Cellular Therapy (ISCT). Cytotherapy 2013;15:641-648.

58 Engels PE, Tremp M, Kingham PJ, di Summa PG, Largo RD, Schaefer DJ, Kalbermatten DF: Harvest site influences the growth properties of adipose derived stem cells. Cytotechnology 2013;65:437-445

59 Guven S, Mehrkens A, Saxer F, Schaefer DJ, Martinetti R, Martin I, Scherberich A: Engineering of large osteogenic grafts with rapid engraftment capacity using mesenchymal and endothelial progenitors from human adipose tissue. Biomaterials 2011;32:5801-5809.
60 Choi JR, Pingguan-Murphy B, Wan Abas WA, Yong KW, Poon CT, Noor Azmi MA, Omar SZ, Chua KH, Xu F, Wan Safwani WK: In situ normoxia enhances survival and proliferation rate of human adipose tissue-derived stromal cells without increasing the risk of tumourigenesis. PLoS One 2015; 10: e0115034.

61 Inda AM, Andrini LB, Garcia MN, Garcia AL, Fernandez Blanco A, Furnus CC, Galletti SM, Prat GD, Errecalde AL: Evaluation of angiogenesis with the expression of VEGF and CD34 in human non-small cell lung cancer. J Exp Clin Cancer Res 2007;26:375-378.

62 Siemerink MJ, Klaassen I, Vogels IM, Griffioen AW, Van Noorden CJ, Schlingemann RO: CD34 marks angiogenic tip cells in human vascular endothelial cell cultures. Angiogenesis 2012;15:151-163.

63 Nisoli E, Regianini L, Briscini L, Bulbarelli A, Busetto L, Coin A, Enzi G, Carruba MO: Multiple symmetric lipomatosis may be the consequence of defective noradrenergic modulation of proliferation and differentiation of brown fat cells. J Pathol 2002;198:378-387.

64 McIntosh KR, Lopez MJ, Borneman JN, Spencer ND, Anderson PA, Gimble JM: Immunogenicity of allogeneic adipose-derived stem cells in a rat spinal fusion model. Tissue Eng Part A 2009;15:2677-2686.

65 Katz A, Mericli A: Stem cells derived from fat; in Atala A, Lanza R, Thomson J, Nerem R (eds): Principles of Regenerative Medicine. San Diego, Elsevier, 2011, pp 365-381.

66 Cherry AB, Gagne KE, McLoughlin EM, Baccei A, Gorman B, Hartung O, Miller JD, Zhang J, Zon RL, Ince TA, Neufeld EJ, Lerou PH, Fleming MD, Daley GQ, Agarwal S: Induced pluripotent stem cells with a mitochondrial DNA deletion. Stem Cells 2013;31: 1287-1297.

67 Mitchell JB, McIntosh K, Zvonic S, Garrett S, Floyd ZE, Kloster A, Di Halvorsen Y, Storms RW, Goh B, Kilroy G, Wu X, Gimble JM: Immunophenotype of human adipose-derived cells: temporal changes in stromal-associated and stem cell-associated markers. Stem Cells 2006;24:376-385.

68 McIntosh K, Zvonic S, Garrett S, Mitchell JB, Floyd ZE, Hammill L, Kloster A, Di Halvorsen Y, Ting JP, Storms RW, Goh B, Kilroy G, $\mathrm{Wu}$ X, Gimble JM: The immunogenicity of human adipose-derived cells: temporal changes in vitro. Stem Cells 2006;24:12461253.

69 Muller AM, Davenport M, Verrier S, Droeser R, Alini M, Bocelli-Tyndall C, Schaefer DJ, Martin I, Scherberich A: Platelet lysate as a serum substitute for $2 \mathrm{D}$ static and $3 \mathrm{D}$ perfusion culture of stromal vascular fraction cells from human adipose tissue. Tissue Eng Part A 2009;15:869-875. 